\title{
12. Ayurvedic Medicines (Yogas) used in Viper Bite (Mandali Sarp) Management - A Review.
}

Author:- Dr.Shashikant D. Wadkar.,Assistant Professor.

Dept. of Agadtantra, Yashwant Ayu. College P.G.T.\& R. C. Kodoli, Email wadkar.sd@gmail.com

Co Author - Dr. Girbide S.G, Professor, Department of Rognidan, Yashwant Ayurvedic College, PGT\&RC, Kodoli,Email-drgirbide@gmail.com

\begin{abstract}
In India it is believed that about 2 million people are bitten by snakes annually of which 15000- 30000 cases prove fatal. There are three families of venomous snakes are of importance in India. In India number of incidences is hare from Viper Bite (Mandali Sarp Dansh). In India $65 \%$ people from rural area use Ayurvedic and Herbal medicines for the treatment of various venomous bites.

The present paper deals with the review of various Yogas (medicines) and treatment of Viper Bite (Mandali Sarp Dansh) described in Ayurveda.
\end{abstract}

Keywards: Ayurvedic Yogas (Medicines), Viper snake (Mandali Sarp)

\section{INTRODUCTION}

Any science such as Ayurveda has its practical findings based on certain concepts. Advances in the knowledge are made possible for the benefit of mankind. Agadatantra, one among the eight branches of Ayurveda details on toxins, their effects on body and its treatment. The fatal cases in the field of poisoning are those of poisonous snakebites. In India it is believed that about 2 million people are bitten by snakes annually, of which 15,000-30,000 cases prove fatal. Though there are 375 species, only 3 families of venomous snakes are of importance in India. Two families are more prevalent in India and number of incidences is more from Viper bite of Viperidae family.

In our country Herpetologists, sarpmitras, trackers, large number of people who stay in villages, mountains and forests are more exposed to snake bites. In these remote areas due to lack of transport facilities and primary aid more people succumb to death.

In India incidence of viper bite is high. No specific anti venom of Viper is available. In viper bite cases early treatment saves the life of the patient. Currently the treatment is only limited with Polyvalent Anti Snake Venom which is available in Government hospitals and it is not easily available in villages, mountains and forest areas and need trained persons for its administration. Also it is not affordable to poor patients.

In this current scenario it is the need of the hour to develop Ayurvedic management as a first aid measure, which will help the patients of snakebite. As the bite cases of Mandali sarp dansh are more and a treatment regime is described in Ayurveda in detail. Hence the aim of present paper was to review the AYURVEDIC yogas and treatment used for the management of viper snake bite. This systematic review was conducted with an objective to search an ideal Ayurvedic regime for viper snake bite.

viper in Ayurvedic view may be 'Venupatraka' a Mandali sarpa on morphological analysis and 'Sopha Mandali' on symptom wise analysis, the subdivision being 'Mula Mandali'. Russell's viper in view a Mandali Sarp on morphological analysis and symptom wise analysis.

\section{MATEIALS AND METHODS}

All relevant information from ayurvedic Samhhitas (Brihatryees) including Vishjyostnika. 


\section{Ayurlog: National Journal of Research in Ayurved Science}

A Web based quarterly online published peer reviewed National E-journal of Ayurveda.

http://www.ayurlog.com

Vol. 01 Issue $1^{\text {st }}$ January- 2013

ISSN 2320-7329

Electronic database search on google was conducted for the review.

Relevant information from already Published various researches on snake bite.

Following Treatment is present in Ayrveda for Viper bite (Mandali Sarp Dansh)

\section{MANDALI SARP DANSH CHIKISTA ACCORDING TO AYURVEDA}

\section{According to Charakacharya}

\section{Chikista According To Vega S.K.5/24-27}

Manjistha, Madhuyashti, Jivak, Vrishabhak, Shweta, Kashmarya, leaf buds of Vata this is the potion for the bite by Mandali type of Sarp.CH.Chi.23/196

\section{According to Susrutacharya}

1. Person who has thirst, burning sensation, increase of body temperature, delusion and other symptoms of Pitta aggravation, should be treated with the cold things, massage, bath and poultices. S.K.5/38

\begin{tabular}{|l|l|}
\hline Vega & Treatment \\
\hline 1. First Vega & Raktamokshan \\
\hline 2. Second Vega & $\begin{array}{l}\text { Agad added with honey and ghee should be given, then } \\
\text { Vaman should be induced and Yavagu given to drink. }\end{array}$ \\
\hline 3. Third Vega & $\begin{array}{l}\text { Shodhan should be done using powerful recipes and } \\
\text { then Yavagu given to drink. }\end{array}$ \\
\hline 4. Fourth Vega & Vaman should be induced and Yavagu given to drink. \\
\hline 5. Fifth Vega & Sheetopchar and Shodhan then Yavagu given to drink. \\
\hline 6. Sixth Vega & $\begin{array}{l}\text { Peya prepared from of Kakolyadi Gana which is sweet } \\
\text { in test and ideal with Agad. }\end{array}$ \\
\hline 7. Seventh Vega & $\begin{array}{l}\text { Anti poisonous Avapida and Agad should be } \\
\text { administered. }\end{array}$ \\
\hline
\end{tabular}

\section{Mandali Dansh Vishesha Yoga}

\section{Drakshadi agad S.K.5/76-77}

Draksha, Sugandha(Sarpgandha), Nagavritika(Shallaki), Sveta, And Samanga all equal quantity forming one part, mixed with two parts of powder of bark of Surasa Kapittha, Bilva, and Dadima and half part of powder of Sitasindhuvara, root of Ankot, and Gairika - all mixed well, added with honey and used; this destroys poison of Mandali.

According to Astang Sangrah \& Astang Hridaya Veganurupa Chikitsa

\begin{tabular}{|l|l|}
\hline Vega & Treatment \\
\hline 1. First Vega & Blood letting, Agad administered with honey and ghee. \\
\hline 2. Second Vega & Vaman and anti poisonous Agad \\
\hline 3. Third Vega & Vaman and then Peya for drink \\
\hline 4 Fourth Vega & \begin{tabular}{l} 
Drinking of Yavagu after Vaman \\
\hline 5 Fifth Vega
\end{tabular} \\
$\begin{array}{l}\text { Body should smeared with cold past of the drugs, frequently } \\
\text { Yaman and then }\end{array}$ \\
\hline
\end{tabular}




\begin{tabular}{|l|l|}
\hline Vega & Treatment \\
\hline 7 Seventh Vega & $\begin{array}{l}\text { He should be administered mild anti poisonous Agad of } \\
\text { Padmakadi Gana } \\
\text { administered, a deep incision resembling the foot of crow is } \\
\text { made on the head with a sharp knife, then a piece of muscle } \\
\text { or skin along with the blood is placed on it. }\end{array}$ \\
\hline
\end{tabular}

Mandali Sarp Dansh Vishesha Yoga A.H.U.36/45, A.S.U.42/9 A.H.U.36/61-62, A.S.U.42/31

Equal parts of Sugandha, Mrudwiaka, Shwetakhya, half part each of leaves of Souras, Kapittha, Bilva, and Dadima Madein to a paste, mixed with honey and used is specially suitable for poison of Mandali.

\section{Himvan Agad}

A.S.U.42/32-33

Barks of Panchavalkala, Vara, Yashti, Nagpushpa, Elavaluka, Jivak, Vrishabhak, Sheetam, Sita, Padmak and Utpala made in to a paste and used mixed with honey. This recipe is known as Himwan Agad, destroy poison of Mandali Sarp by external application it cures swelling Visarp, Visphota, Jwar, Daha.

\section{A.H.U.36/65, A.S.U.42/34}

Kashamarya, Vatashunga, Jivak, Vrishabhak, Sita, Manjistha And Madhuka made into a paste and consumed cures the poisoning of Mandali Sarp.

\section{Astang Agad A.H.U.36/66}

Bark and seeds of Vansha, Katuka, seed of Patali, Nagar, seeds of Shirish, Ativisha, roots of Gavedhuka, and Vacha made into a paste with cows urine. This recipe is known as Astang Agad consumed cures the poisoning of Gonas Sarp.

\section{MANDALI SARP DANSH CHIKISTA ACCORDING TO VISHA VAIDYA JYOTSNIKA}

Treatment of Mandali visha

Visha Vaidya Jyotsnika. Medications for Mandali Visha are prescribed for intake and for external application on the bite site, Dhara, nasal and collyrium application.

\section{Panadivogas}

1. The root of Nili(Indigofera tinctoria), Patala (Stereospermum suaveolens)the root bark of Karanja(Pongamia glabra) and Pata (Cyclea peltata) each separately can be taken internally grinded with Luke warm water. The paste of each drug is applied externally as lepa on the site of snake bite.

2. The drug Chandana (Santalum album) with cold water is taken internally.

3. The root bark of the white variety of Kasamarda(Canthum parviflora) is taken internally.

4. The root of Sarpagandha (Rauwolfia serpentina) , Vacha (Acorus calamus) and Seetha (Coleus ambonicus veltereroides)is taken internally.

5. The root of Karaskara (Strychnos nuxvomica) is grinded and paste is applied externally on the site of Mandalidansha.

6. The paste of Sariva (Hemidesmus indicus) and Vacha (Acorus calamus) can be used in the same way.

7. Equal quantity of Yashti madhu (Glycyrrhiza glabra) Chandana (Santalum album) and Usheera (Veteveria zizanioides) is applied as nasal medicine and collyrium application and internally.

8. The drugs Gandhara (Capparis spinosa) and Eeshwaramooli (Aristolochia indica) can be administered internally.

9. The roots of Punarnava (Boerrhavia diffusa) and Arka (Calotropis procera) is 
applied internally in the form of juice and externally as paste on the site of Mandalidansha.

10. The internal application of equal quantity of Lodhra (Symplocos racemosa) Seetha( Coleus ambonicus veltereroides) Haridra(Curcuma longa) Daruharidra(Coccinium fenestratum), Sarala (Sesalpinia sappan ), Arka (Calotropis procera ), Manjishta (Rubia cordifolia), root of Patala (Stereospermum suaveolens) with Vilwa (Aegle marmeoles) is very effective.

11. Equal quantity of the Tagara (Valeriana wallichii) Chandana (Santalum album),Kushta (Saussurea lappa), Yashtimadhu (Glycyrrhiza glabra) Usheera (Veteveria zizanioides), Sariva (Hemidesmus indicus) is used internally as decoction and externally as paste on the site of Mandalidansha. This yoga has the same ingredients of Kottamtagaradi, one of the study drugs, but in a different version.

12. The root of Nimba (Azadirachta indica) Nili (Indigofera tinctoria), Karanja (Pongamia glabra) is used internally as decoction and externally as paste,

13. The drugs Murva (Marsenia tenascissima), tuber of Pata (Cyclea peltata) ,rock salt, Vacha (Acorus calamus) is used internally as decoction and externally as paste on the site of Mandalidansha.

\section{Lepayogas for Mandali Dansha}

1. The paste made by roots of Punnarnava (Boerrhavia diffusa) Sigru (Moringa olifera) Shireesha (Albizzia lebbeck) and Ashwagandha(Withania somnifera).

2. The paste made by grinding the barks of Amra(Mangifera indica),Karanja(Pongamia glabra),Amlika (Tamarindus indicus), and

3. Eshwaramooli (Aristolochia indica), Vacha(Acorus calamus), root of Pata (Cyclea peltata), Haridra (Curcuma longa) in rice washed water.

4. The paste made by removing half of seeds from Datura (Datura metal) with small quantity of salt and rice washed water.
5. Kushta (Saussurea lappa), Tagara(Valeriana wallichii) Usheera (Vetiveria zizanoides), Chandana (Santalum album) Yashtimadhu(Glycyrrhiza glabra) Sariva(Hemidesmus indicus) are grinded and the paste is applied externally at the bite site and at vertex and internally as decoction and nasal application. A detailed study of this yoga is given in Drug study.

6. Roots of Punarnava (Boerrhavia diffusa), Arka (Calotropis procera), Eshwaramooli(Aristolochia indica), Gokshura (Tribulus terrestris), Pata (Cyclea peltata, Vacha (Acorus calamus), Chandana(Santalum album) Haridra(Curcuma longa), bark of Aghori(Flacourtia indica) and Karanja (Pongamia glabra) are grinded with rice washed water.

7. Gentle massage with cow's ghee and rock salt for pain, heat and swelling of vrana.

Pindika sweda prayogas Leaves of Arishtamanjari (Acalypha indica) Kalasaka (Murrya koennija) Uttama kanya (Pergularia extensa) Arka (Calotropis procera) Amlika (Tamarindus indica) Datura(Datura metal) Gandhara (Capparis spinosa) and Shigru(Moringa olifera) are grinded with rice washed water and mixed with buffalo dung. The boluses enclosed within a cloth are heated with rice washed water or cow's urine in a closed earthen vessel and used for gentle massage on the swelling. The juice extracted from the above drugs is used for dhara and a paste can be used as external application.

\section{Dharayogas}

Chandana (Santalum album) is grinded and mixed with water is used for dhara. It is very effective to reduce complications due to Mandali bite.

Tikhapimbi(Trichosanthus

tricuspidata), Sargheshta (Cardiospermum halicacabum), the root of Shatavari (Asparagus racemosa) grinded and mixed

With rice washed water is used for dhara to reduce swelling, pain, feeling of extreme heat and fatigue. 


\section{Ayurlog: National Journal of Research in Ayurved Science \\ A Web based quarterly online published peer reviewed National E-journal of Ayurveda.}

\section{Thookkudhara}

Here dhara pot is hanging on ropes above the body of patient. Dharadrava is poured slowly through the hole in the centre of the pot through a cotton wick.If leaves of Nimba (Azadirachta indica) are kept in the pot is very beneficial. Vriksharuha (Loranthus ingiflorus) which is on Karaskara (Strychnos nuxvomica), Chandana(Santalum

album.),Shathavari(Asparagus racemosa), juice of Kumari (Aloe vera) leaves of Kusmanda (Benincasa hispida), Eranda (Ricinus communis) are grinded and mixed with water is used for dhara for reducing burning sensation, swelling, feeling of extreme heat etc.

\section{DISCUSSION}

The present paper includes various Yogas (medicines) used in Ayurveda for Viperbite management (Mandali sarp Dansh). All the constituents of these Yogas are easily available and having anti poisonous properties. The method of preparation and mode af administration of these Yogas is convenient. Blending these Yogas and treatment with anti snake venom may also be a good perceptive and question for the research in future.

\section{CONCLUSION}

The main objective of the present paper was to study the Ayurvedic management of mandali Sarp Dansh and establish a regime for the Mandali sarp Dansh as first aid measure.

After detailed gretical review following conclusion are evolved.

1 Viper snakes are venomous snakes and from their correlation with external morphology, signs and symptom after bite they are very much similar with Mandali sarp described in Ayurveda.

2 Ayurvedic management of sarp dansh can be divided in two parts one is daivavyapashrya and other is Yuktivyapshraya. Where former one includes the use of mantra chikitsa and later one various drugs, yogas, and shodhan procedures.

3 After this review we can establish the Ayurvedic regime for Mandali sarp Dansh (Viper bite) as a first aid measure.

4 Future study of these treatment and medicine(Yogas) for their constituent's chemical composition and their pharmacological action may help to increase efficacy and authenticity.

\section{REFERENCES:}

\begin{tabular}{|c|c|c|c|c|}
\hline $\begin{array}{l}\text { Sr. } \\
\text { No. }\end{array}$ & Name of book & Editor/Author & Publisher & $\begin{array}{l}\text { Edition } \\
\& Y \text { ear }\end{array}$ \\
\hline 1 & Ashtang Hridaya & $\begin{array}{l}\text { Dr. Ganesh Krishana } \\
\text { Gadre }\end{array}$ & Anamol Prakashan Pune & Reprint 1990 \\
\hline 2 & Ashtang sangraha & $\begin{array}{l}\text { Punyashlok Shri } \\
\text { Pandit Lalchand } \\
\text { Shastri Vidya }\end{array}$ & $\begin{array}{l}\text { Baidhanath Ayurveda } \\
\text { Bhavan Pvt. Ltd. }\end{array}$ & $\begin{array}{l}1^{\text {st }} \\
1988\end{array}$ \\
\hline 3 & Charak Samhita & $\begin{array}{l}\text { Dr. Bramhanand } \\
\text { Tripathi }\end{array}$ & $\begin{array}{l}\text { Chaukhamba \& Surbhartati } \\
\text { Prakashan Varanasi }\end{array}$ & Reprint 20003 \\
\hline 4 & Sushurat Samhita & $\begin{array}{l}\text { Kaviraj Ambikadatta } \\
\text { Shastri }\end{array}$ & $\begin{array}{ll}\text { Chaukhambha } & \text { Sanskrit } \\
\text { Sanstha Varanasi } & \end{array}$ & $\begin{array}{l}14^{\text {th }} \\
2003\end{array}$ \\
\hline 5 & $\begin{array}{l}\text { Visha Vaidya } \\
\text { Sara Samuchaya }\end{array}$ & $\begin{array}{l}\text { Cheruklappurath } \\
\text { Krishana Namboodri }\end{array}$ & $\begin{array}{ll}\text { Ullonar Mana } & \text { Trust } \\
\text { Venkaitangu Trissur } & \end{array}$ & 2006 \\
\hline
\end{tabular}




\section{Ayurlog: National Journal of Research in Ayurved Science}

A Web based quarterly online published peer reviewed National E-journal of Ayurveda.

\section{http://www.ayurlog.com}

Vol. 01 Issue $1^{\text {st }}$ January- 2013

ISSN 2320-7329

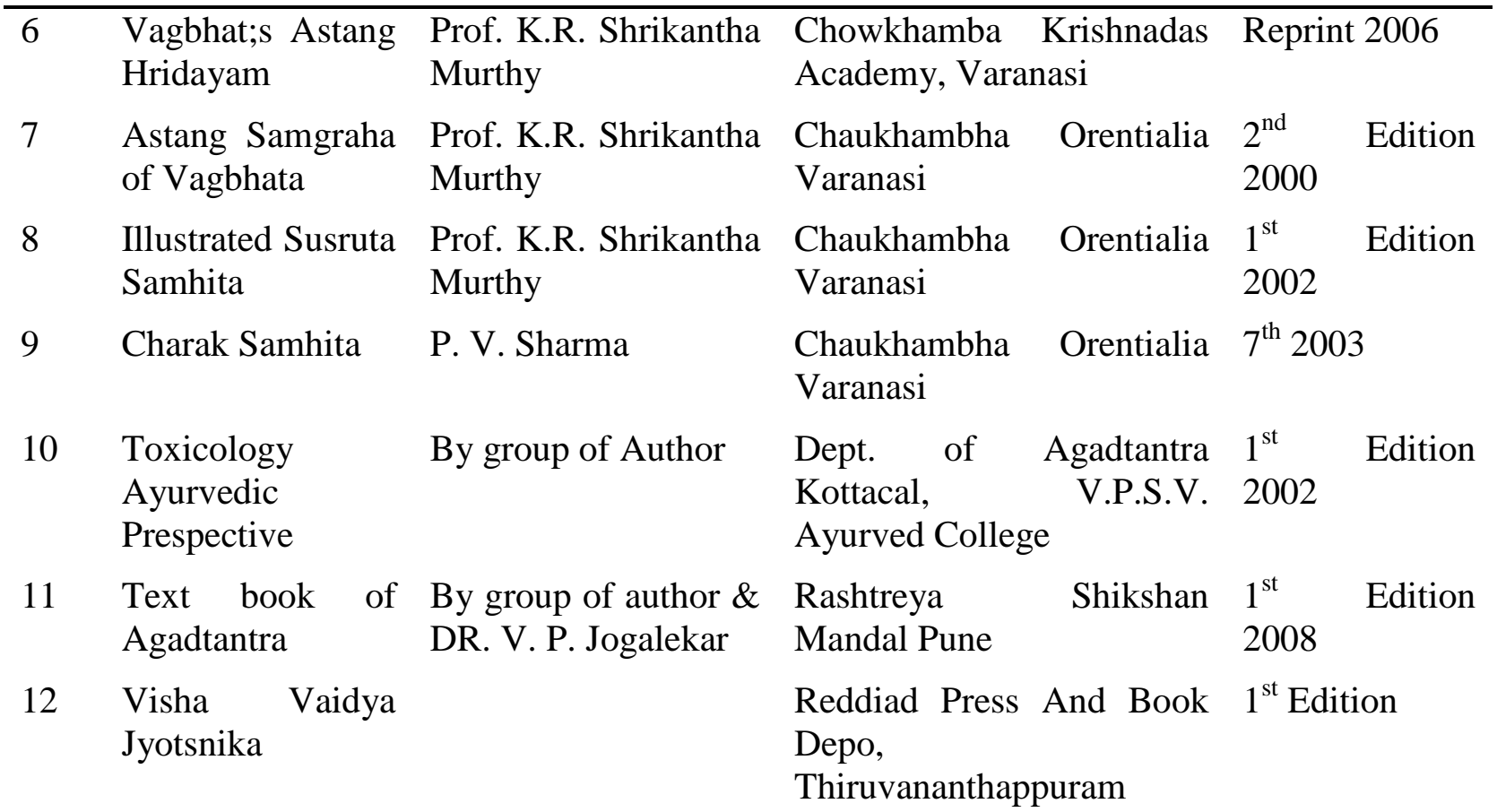

13 Sirosha M. - (2006), A comparative study on efficacy of Kottamtagaradi yoga wit Sigrupunarnavadi yoga in Trimeresurus gramineus bite Kottakkal.

14 Nitin Urmalia - (2009) An Evaluation of treatment modality of Mandali damsa with Ajitagada in clinical and experimental level. Kottakkal.

15 Savita - (2009) In vivo study of the efficacy of Aragvadh Pushapa Swaras as first aid measure in snake bite. Pune

16 http://en. Wikipedia.org/snake-files/

17 Internet source. 